\title{
PENERAPAN METODE PEMBELAJARAN KOOPERATIF TEKNIK THINK PAIR \\ SHARE UNTUK MENINGKATKAN MOTIVASI BELAJAR AKUNTANSI \\ KOMPETENSI DASAR MENGHITUNG MUTASI DANA KAS KECIL \\ SISWA KELAS X AKUNTANSI 2 SMK NEGERI 7 YOGYAKARTA \\ TAHUN AJARAN 2011/2012
}

Oleh :

Hana Kurniawan ${ }^{1}$

Andian Ari Istiningrum ${ }^{2}$

\begin{abstract}
Abstrak
Penelitian ini adalah Penelitian Tindakan Kelas (Classroom Action Research) yang bertujuan untuk meningkatkan Motivasi Belajar Akuntansi Kompetensi Dasar Menghitung Mutasi Dana Kas Kecil siswa kelas X Akuntansi 2 SMK Negeri 7 Yogyakarta Tahun Ajaran 2011/2012 melalui penerapan Metode Pembelajaran Kooperatif Teknik Think Pair Share (TPS). Penelitian ini dilaksanakan dalam bentuk kolaboratif yang dilaksanakan selama dua siklus.

Pengumpulan data dalam penelitian ini dilakukan dengan observasi, angket dan wawancara. Analisis data yang digunakan adalah analisis kualitatif dan analisis kuantitatif. Analisis kualitatif dilakukan dengan mereduksi data, menyajikan data dan menarik kesimpulan, sedangkan analisis kuantitatif dilakukan dengan membandingkan perolehan skor Motivasi Belajar Akuntansi dengan skor maksimum kemudian dipersentasekan.

Berdasarkan hasil penelitian disimpulkan bahwa Penerapan Metode Pembelajaran Kooperatif Teknik Think Pair Share (TPS) dapat meningkatkan Motivasi Belajar Akuntansi Kompetensi Dasar Menghitung Mutasi Dana Kas Kecil siswa kelas X Akuntansi 2 SMK Negeri 7 Yogyakarta tahun ajaran 2011/2012 yang dibuktikan dengan adanya peningkatan persentase skor Motivasi Belajar Akuntansi sebesar 16,28\% dari sebelum penerapan Pembelajaran Kooperatif Teknik Think Pair Share (TPS) sebesar 53,31\% meningkat menjadi $69,60 \%$ di siklus 1 . Selanjutnya dari siklus 1 ke siklus 2 juga terjadi peningkatan sebesar $11,47 \%$ atau diperoleh skor sebesar $81,07 \%$. Selain itu berdasarkan angket yang didistribusikan kepada siswa dapat disimpulkan pula bahwa terjadi peningkatan skor Motivasi Belajar Akuntansi siswa sebesar 4,18\% dari skor siklus 1 sebesar 70,86\% ke siklus 2 sebesar 75,04\%. Dengan cross check yang dilakukan melalui wawancara diperoleh pula hasil bahwa sebagian besar data yang diperoleh konsisten dengan data observasi dan data angket.
\end{abstract}

\footnotetext{
${ }^{1}$ Alumni Program Studi Pendidikan Akuntansi UNY

${ }^{2}$ Dosen Jurusan Pendidikan Akuntansi UNY
} 
Kata Kunci: Pembelajaran Kooperatif, Think Pair Share, Motivasi Belajar Akuntansi, SMK Negeri 7 Yogyakarta

\section{A. Pendahuluan}

\section{Latar Belakang Masalah}

Motivasi sebagai salah satu faktor psikologis dalam proses belajar memiliki makna sebagai dorongan mental yang menimbulkan adanya daya penggerak dalam diri siswa yang menimbulkan kegiatan belajar kemudian memelihara kelangsungan belajar dan memberikan arah pada pencapaian tujuan belajar (Sardiman, 2011: 75). Tinggi rendahnya motivasi belajar siswa dapat dipengaruhi oleh bermacam-macam hal. Jika dikelompokkan lagi dapat diklasifikasikan menjadi dua yaitu faktor internal dan eksternal. Seperti yang diungkapkan oleh Dimyati dan Mudjiono (2009: 97-100) mengungkapkan bahwa motivasi belajar siswa dapat dipengaruhi oleh cita-cita atau aspirasi siswa, kemampuan siswa, kondisi siswa, lingkungan siswa, unsur-unsur dinamis dalam belajar dan upaya guru dalam membelajarkan siswa termasuk metode pembelajaran yang disajikan guru. Salah satu faktor penting yang memberikan pengaruh terhadap proses belajar mengajar adalah pendekatan belajar. Pembelajaran yang mampu membuat siswa termotivasi adalah pembelajaran yang menarik, bermakna, dan memberi tantangan. Untuk menciptakan kondisi pembelajaran di atas perlu diperhatikan empat aspek penting dalam pembelajaran agar motivasi belajar siswa dapat terpelihara yaitu perhatian (attention), relevansi (relevance), kepercayaan diri (confidence), dan kepuasan (satisfaction) (Sugihartono et. al, 2007: 79-80).

Metode pembelajaran yang berorientasi pada peningkatan motivasi dan aktivitas siswa salah satunya adalah metode pembelajaran kooperatif Teknik Think Pair Share (TPS). Michaels dalam (Etin Solihatin dan Raharjo, 2007: 15) mengatakan bahwa "Cooperative learning is more effective in increassing motive and performance students". Dalam pembelajaran kooperatif, siswa akan berinteraksi dengan siswa lain dan banyak melakukan aktivitas belajar dalam kelompoknya. Siswa bekerja dalam kelompoknya sekaligus bertanggungjawab atas kesuksesan kelompoknya. Setiap anggota dalam kelompok memiliki

saling ketergantungan positif, sehingga memicu setiap anggota untuk selalu berperan aktif dalam kelompoknya. Dengan keadaan semacam ini, pembelajaran kooperatif dapat menyuguhkan kondisi pembelajaran yang menarik, bermakna dan menantang yang kemudian dapat meningkatkan motivasi belajar menjadi tinggi. 


\section{Jurnal Pendidikan Akuntansi Indonesia, Vol. X, No. 1, Tahun 2012 Hana Kurniawan \& Andian Ari Istiningrum \\ Halaman $114-134$}

Berdasarkan observasi awal yang dilakukan tanggal 27 Maret 2012 di kelas X Akuntansi 2 SMK Negeri 7 Yogyakarta diketahui bahwa motivasi belajar siswa dalam mengikuti pembelajaran Akuntansi masih rendah. Sebanyak 24,24\% siswa menyelesaikan sebagian besar soal yang diberikan dan $75,76 \%$ tidak fokus dalam mengerjakan. Jika terdapat soal atau materi yang belum dipahami terdapat $81,82 \%$ siswa hanya diam dan tidak berusaha mencari pemecahannya. Sebanyak 51,52\% kadang-kadang memperhatikan penjelasan guru dan mengobrol di luar materi. Dalam mengerjakan soal, terdapat $18,18 \%$ siswa memilih berdiam diri menunggu jawaban teman. Pada saat pembelajaran hendak dimulai 81,82\% siswa menyiapkan peralatan yang diperlukan setelah adanya perintah dari guru. Ketika siswa ditanya oleh guru sebanyak $12,12 \%$ siswa tidak dapat memberikan jawaban atas pertanyaan guru. Dalam mengerjakan soal yang diberikan guru 15,15\% siswa mengerjakan sebagian soal saja. Terdapat $6,06 \%$ siswa yang mengerjakan soal begitu ada perintah guru dan 93,95\% menunda-nunda dalam mengerjakan. Selain itu hanya 3,03\% siswa yang mengumpulkan tugas begitu diminta dan 93,94\% siswa menunda-nunda mengumpulkan tugas tersebut.

Intensitas ceramah dan latihan soal yang terlalu banyak dalam pembelajaran Akuntansi juga ditemukan di kelas X Akuntansi 2 SMK Negeri 7 Yogyakarta. Siswa lebih banyak diam mendengarkan ceramah dari guru. Kondisi seperti ini akan mengarah kepada adanya pembelajaran Akuntansi yang kurang menarik, kurang menantang dan cenderung tidak bermakna bagi siswa, sehingga pembelajaran yang ada belum mampu menggugah motivasi belajar siswa. Untuk itu perlu dilakukan upaya untuk mencari penyebabnya kemudian mendorong siswa agar mau melakukan apa yang seharusnya dilakukan yaitu belajar. Berdasarkan uraian yang dijelaskan di atas peneliti mencoba untuk melakukan penelitian dengan judul "Penerapan Metode Pembelajaran Kooperatif Teknik Think Pair Share (TPS) untuk Meningkatkan Motivasi Belajar Akuntansi Kompetensi Dasar Menghitung Mutasi Dana Kas Kecil Siswa Kelas X Akuntansi 2 SMK Negeri 7 Yogyakarta Tahun Ajaran 2011/2012”.

\section{Tujuan Penelitian}

Tujuan penelitian ini adalah untuk meningkatkan Motivasi Belajar Akuntansi Kompetensi Dasar Menghitung Mutasi Dana Kas Kecil siswa Kelas X Akuntansi 2 SMK Negeri 7 Yogyakarta Tahun Ajaran 2011/2012. 


\section{Kajian Teori}

\section{a. Motivasi Belajar Akuntansi}

Motivasi Belajar Akuntansi merupakan dorongan mental yang dimiliki siswa dalam mengkonstruksi fakta-fakta, ide-ide dan pengalamannya untuk menambah pengetahuannya tentang kegiatan pencatatan dan pengikhtisaran transaksi keuangan yang bertujuan menyediakan informasi ekonomi yang berguna bagi pihak-pihak yang berkepentingan guna mencapai prestasi belajar yang maksimal. Menurut Sardiman (2011: 83), seseorang yang memiliki motivasi belajar tinggi memiliki ciri-ciri sebagai berikut:

1) Tekun menghadapi tugas

2) Ulet menghadapi kesulitan (tidak lekas putus asa)

3) Menunjukkan minat terhadap bermacam-macam masalah untuk orang dewasa

4) Lebih senang bekerja mandiri

5) Cepat bosan pada tugas-tugas rutin

6) Dapat mempertahankan pendapatnya

7) Tidak mudah melepaskan hal yang diyakini itu

8) Senang mencari dan memecahkan masalah soal-soal

\section{b. Metode Pembelajaran Kooperatif Teknik Think Pair Share (TPS)}

Menurut Wina Sanjaya (2008: 240) Metode Pembelajaran Kooperatif adalah metode pembelajaran dengan sistem pengelompokan yang beranggotakan beberapa siswa yang mempunyai latar belakang kemampuan heterogen. Teknik Think Pair Share (TPS) merupakan salah satu teknik yang dapat diterapkan dalam pembelajaran kooperatif. Teknik ini mengandung tiga unsur penting yaitu Think (Berpikir), Pair (Berpasangan) dan Share (Berbagi). Berikut ini langkah-langkah dalam Pembelajaran Kooperatif Teknik Think Pair Share (TPS) menurut Yatim Riyanto (2009: 278-279):

1) Guru menyampaikan topik inti materi dan kompetensi yang ingin dicapai

2) Siswa diminta untuk berpikir tentang topik materi atau permasalahan secara individual

3) Siswa diminta berpasangan dengan teman sebelahnya (kelompok 2 orang) dan mengutarakan hasil pemikirannya masing-masing tentang topiknya tadi

4) Guru memimpin pleno kecil diskusi. Tiap kelompok pasangan mengemukakan hasil diskusinya untuk berbagi jawaban (Share) dengan seluruh siswa dikelas

5) Mengarahkan pembicaraan pada topik pokok permasalahan dan menambah materi yang belum diungkapkan para siswa

6) Guru memberi kesimpulan

7) Penutup 


\section{B. Metode Penelitian}

\section{Desain Penelitian}

Penelitian ini adalah Penelitian Tindakan Kelas (Classroom Action Research) dalam bentuk kolaborasi. Peneliti bersama dengan guru mata pelajaran berkolaborasi melaksanakan penelitian ini sebanyak dua siklus. Adapun prosedur yang digunakan adalah proses penelitian tindakan model Kemmis dan Taggart, dimana terdapat 8 tahapan yaitu Perencanaan Pertama, Tindakan Pertama, Pengamatan Pertama, Refleksi Pertama, Revisi Terhadap Perencanaan Pertama, Tindakan Kedua, Pengamatan Kedua, dan, Refleksi Kedua.

\section{Subjek dan Objek Penelitian}

Subjek penelitian ini adalah seluruh siswa kelas X Akuntansi 2 SMK Negeri 7 Yogyakarta Tahun Ajaran 2011/2012. Adapun jumlah siswa kelas tersebut yaitu berjumlah 35 siswa. Sedangkan objek penelitian ini adalah Motivasi Belajar Akuntansi siswa kelas X Akuntansi 2 SMK Negeri 7 Yogyakarta Tahun Ajaran 2011/2012.

\section{Instrumen Penelitian}

\section{a. Pedoman Observasi}

Observasi yang dilakukan membutuhkan adanya pedoman tertulis yang memuat indikator-indikator yang akan diamati. Berikut ini pedoman observasi untuk pengamatan yang akan dilaksanakan:

Tabel 1. Pedoman Observasi

\begin{tabular}{|l|c|c|}
\hline \multicolumn{1}{|c|}{ Indikator } & Nomor Butir & Sumber Data \\
\hline Tekun menghadapi tugas & 1,2 & Siswa \\
\hline Ulet menghadapi kesulitan & 3,4 & Siswa \\
\hline Memiliki minat terhadap pelajaran & 5,6 & Siswa \\
\hline Lebih senang bekerja mandiri & 7,8 & Siswa \\
\hline Cepat bosan pada tugas-tugas rutin & 9,10 & Siswa \\
\hline Dapat mempertahankan pendapatnya & 11,12 & Siswa \\
\hline Tidak mudah melepaskan hal yang diyakini & 13,14 & Siswa \\
\hline Senang mencari dan memecahkan masalah soal-soal & 15,16 & Siswa \\
\hline
\end{tabular}

Berdasarkan indikator di atas, peneliti memberikan skor kepada masing-masing aspek yang akan diamati menggunakan skala likert empat jawaban alternatif yaitu sangat baik, baik, tidak baik dan sangat tidak baik (Sugiyono, 2010: 135). 


\section{b. Angket}

Angket adalah instrumen yang digunakan untuk mengumpulkan data tentang Motivasi Belajar Akuntansi siswa dilihat dari sudut pandang siswa. Berikut kisi-kisi angket yang digunakan:

Tabel 2. Kisi-Kisi Angket Motivasi Belajar Akuntansi

\begin{tabular}{|l|c|c|}
\hline \multicolumn{1}{|c|}{ Indikator } & No butir & Jumlah \\
\hline Tekun menghadapi tugas & $1,2,3,4$ & 4 \\
\hline Ulet menghadapi kesulitan & $5,6,7$, & 3 \\
\hline Memiliki minat terhadap pelajaran & $8,9,10$ & 3 \\
\hline Lebih senang bekerja mandiri & $11,12,13$ & 3 \\
\hline Cepat bosan pada tugas-tugas rutin & $14,15,16$ & 3 \\
\hline Dapat mempertahankan pendapatnya & $17,18,19$ & 3 \\
\hline Tidak mudah melepaskan hal yang diyakini & $20,21,22$ & 3 \\
\hline Senang mencari dan memecahkan masalah soal-soal & $23,24,25$ & 3 \\
\hline \multicolumn{2}{|c|}{ Jumlah } & \\
\hline
\end{tabular}

\section{c. Pedoman Wawancara}

Pada penelitian kali ini, peneliti menggunakan pedoman wawancara semi terstruktur untuk memperoleh data tentang Motivasi Belajar Akuntansi. Hal ini dimaksudkan agar tercipta kondisi yang nyaman ketika wawancara. Berikut ini pedoman wawancara yang akan digunakan:

Tabel 3. Pedoman Wawancara

\begin{tabular}{|c|l|c|c|}
\hline No & \multicolumn{1}{|c|}{ Indikator } & $\begin{array}{c}\text { Nomor } \\
\text { Butir }\end{array}$ & $\begin{array}{c}\text { Sumber } \\
\text { Data }\end{array}$ \\
\hline 1 & Tekun menghadapi tugas & 1,2 & Siswa \\
\hline 2 & Ulet menghadapi kesulitan & 3,4 & Siswa \\
\hline 3 & Memiliki minat terhadap pelajaran & 5,6 & Siswa \\
\hline 4 & Lebih senang bekerja mandiri & 7,8 & Siswa \\
\hline 5 & Cepat bosan pada tugas-tugas rutin & 9,10 & Siswa \\
\hline 6 & Dapat mempertahankan pendapatnya & 11,12 & Siswa \\
\hline 7 & Tidak mudah melepaskan hal yang diyakini & 13,14 & Siswa \\
\hline 8 & Senang mencari dan memecahkan masalah soal-soal & 15,16 & Siswa \\
\hline
\end{tabular}

\section{d. Catatan Lapangan}

Catatan lapangan merupakan catatan yang berfungsi untuk mencatat berita acara pelaksanaan pembelajaran dengan Metode Pembelajaran Kooperatif Teknik Think Pair Share (TPS). Catatan lapangan juga digunakan untuk membantu dalam proses refleksi. 


\section{e. Triangulasi}

Dalam penelitian ini untuk menguji kredibilitas data digunakan triangulasi teknik. "Triangulasi teknik untuk menguji kredibilitas data dilakukan dengan cara mengecek data kepada sumber yang sama dengan teknik yang berbeda" (Sugiyono, 2010: 373).

\section{Teknik Analisis Data}

\section{a. Analisis Data Kualitatif}

Penelitian ini menggunakan Teknik Analisis Kualitatif yang dikembangkan Miles Huberman (Sugiyono, 2010: 246). Teknik analisis data yang digunakan dalam penelitian ini meliputi:

a) Reduksi Data

Penyederhanaan data tersebut dilakukan melalui seleksi data, pemfokusan dan pengabstraksian data mentah menjadi data yang lebih sederhana dan memiliki makna.

b) Penyajian Data

Data selanjutnya akan diorganisasikan dan dideskripsikan dalam pemaparan secara naratif yang dapat dimaknai secara lebih baik.

c) Penarikan Kesimpulan

Penarikan kesimpulan adalah proses pengambilan intisari dari data-data yang telah disajikan secara terorganisir menjadi bentuk pernyataan yang memiliki makna yang lebih tegas.

\section{b. Analisis Data Kuantitatif}

Data yang diperoleh dari pengamatan dan angket selanjutnya dilakukan analisis untuk mengetahui skor Motivasi Belajar Akuntansi siswa. Dari hasil persentase yang diperoleh akan diketahui sejauh mana peningkatan Motivasi Belajar Akuntansi siswa. Dari hasil analisis data observasi tersebut kemudian disajikan dalam bentuk uraian deskriptif.

Untuk menganalisis secara kuantitatif dilakukan langkah-langkah sebagai berikut:

a) Menentukan kriteria pemberian skor terhadap masing-masing deskriptor pada setiap aspek motivasi belajar siswa yang diamati.

b) Menjumlahkan skor untuk masing-masing aspek motivasi belajar yang diamati.

c) Menghitung skor motivasi belajar pada setiap aspek yang diamati dengan rumus: 


$$
\%=\frac{\text { Skor Hasil Motivasi Belajar Akuntansi Siswa }}{\text { Skor Maksimum }} \times 100 \%
$$

(Sugiyono, 2010: 137)

\section{Indikator Keberhasilan}

Kriteria keberhasilan dari penelitian tindakan ini adalah adanya peningkatan Motivasi Belajar Akuntansi siswa kelas X Akuntansi 2 SMK Negeri 7 Yogyakarta selama pembelajaran Akuntansi berlangsung. Dilihat dari segi proses, pembelajaran dikatakan berhasil dan berkualitas jika seluruhnya atau minimal (75\%) siswa terlibat aktif dan menunjukkan kegairahan belajar yang tinggi, semangat belajar yang besar dan rasa percaya diri yang tinggi (Mulyasa, 2006: 174). Tindakan ini dinyatakan berhasil sekurang-kurangnya diperoleh persentase Motivasi Belajar Akuntansi yaitu 75\%.

\section{Hasil Penelitian dan Pembahasan \\ 1. Hasil Penelitian \\ a. Observasi Awal}

Sebelum diterapkan Metode Pembelajaran Kooperatif Teknik Think Pair Share (TPS) di kelas X Akuntansi 2 SMK Negeri 7 Yogyakarta, peneliti melakukan observasi awal pembelajaran Akuntansi yang dilaksanakan guru dengan menggunakan metode yang biasanya yaitu ceramah dan latihan soal. Observasi dilaksanakan pada tanggal 27 Maret 2012 di kelas X Akuntansi 2 pada jam pertama sampai dengan jam ketiga dengan materi rekonsiliasi bank. Dari observasi yang dilakukan diperoleh data sebagai berikut:

Tabel 4. Skor Motivasi Belajar Akuntansi Siswa Sebelum Penerapan Metode Pembelajaran Kooperatif Teknik Think Pair Share (TPS)

\begin{tabular}{|c|l|c|}
\hline No & \multicolumn{1}{|c|}{ Indikator } & Skor \\
\hline 1 & Tekun menghadapi tugas & $53,79 \%$ \\
\hline 2 & Ulet menghadapi kesulitan & $55,30 \%$ \\
\hline 3 & Memiliki minat terhadap pelajaran & $62,12 \%$ \\
\hline 4 & Lebih senang bekerja mandiri & $46,59 \%$ \\
\hline 5 & Cepat bosan pada tugas-tugas rutin & $56,06 \%$ \\
\hline 6 & Dapat mempertahankan pendapatnya & $50,38 \%$ \\
\hline 7 & Tidak mudah melepaskan hal yang diyakini & $51,14 \%$ \\
\hline 8 & Senang mencari dan memecahkan masalah soal-soal & $51,14 \%$ \\
\hline Skor Rata-rata & $53,31 \%$ \\
\hline
\end{tabular}

Sumber: Data Primer yang Diolah

Dari data di atas menunjukkan skor Motivasi Belajar Akuntansi siswa kelas X Akuntansi 2 SMK Negeri 7 Yogyakarta diukur dari delapan indikator yang telah ditentukan 
yaitu sebesar 53,31\%. Hal ini bermakna bahwa Motivasi Belajar Akuntansi siswa belum mencapai kriteria minimum yang ditentukan yaitu $75 \%$.

\section{b. Laporan Siklus 1}

Pembelajaran Akuntansi dengan Metode Pembelajaran Kooperatif Teknik Think Pair Share siklus 1 dilaksanakan pada tanggal 30 Maret 2012 pada jam pelajaran pertama sampai dengan jam ketiga dengan materi mengidentifikasi saldo awal dana kas kecil, mengidentifikasi bukti pemakaian dana kas kecil, menghitung jumlah pemakaian dana kas kecil dan menghitung selisih dana kas kecil. Adapun tahapan yang dilakukan sebagai berikut:

1) Tahap Perencanaan

Dilakukan beberaa persiapan untuk pembelajaran yang dilaksanakan dengan Metode Pembelajaran Kooperatif Teknik Think Pair Share. Persiapan yang dilakukan meliputi:

a) Membuat Rencana Pelaksanaan Pembelajaran (RPP)

b) Membuat pedoman observasi

c) Menyiapkan angket

d) Membagi siswa menjadi pasangan-pasangan

e) Menyiapkan perlengkapan untuk menunjang pembelajaran TPS

2) Tahap Pelaksanaan

Pada dasarnya tahap pelaksanaan merupakan pengimplementasian dari RPP yang telah dirancang pada tahap persiapan. Adapun pengimplementasiannya sebagai berikut:

a) Kegiatan Awal

(1) Guru mengkondisikan kelas

(2) Guru menyampaikan inti topik materi

b) Kegiatan Inti

(1) Guru mengumumkan daftar pasangan siswa dan tempat duduknya.

(2) Masing-masing siswa diberikan soal untuk dipikirkan jawaban sementaranya

(3) Siswa diminta untuk bekerjasama dengan pasangannya

(4) Setelah siswa selesai mengerjakan kemudian diminta untuk berbagi

c) Kegiatan Akhir

(1) Guru bersama-sama dengan siswa melakukan konfirmasi

(2) Guru mengakhiri pembelajaran

3) Tahap Pengamatan 
Pengamatan dilakukan pada proses pembelajaran yang berlangsung di kelas menggunakan Metode Pembelajaran Kooperatif Teknik Think Pair Share (TPS). Peneliti menggunakan lembar observasi yang telah disusun sebelumnya. Dari pengamatan yang dilakukan diperoleh data sebagai berikut:

Tabel 5. Skor Motivasi Belajar Akuntansi Siswa Siklus 1

\begin{tabular}{|c|l|c|}
\hline No & \multicolumn{1}{|c|}{ Indikator } & Skor \\
\hline 1 & Tekun menghadapi tugas & $84,29 \%$ \\
\hline 2 & Ulet menghadapi kesulitan & $69,29 \%$ \\
\hline 3 & Memiliki minat terhadap pelajaran & $78,57 \%$ \\
\hline 4 & Lebih senang bekerja mandiri & $76,07 \%$ \\
\hline 5 & Cepat bosan pada tugas-tugas rutin & $64,64 \%$ \\
\hline 6 & Dapat mempertahankan pendapatnya & $51,79 \%$ \\
\hline 7 & Tidak mudah melepaskan hal yang diyakini & $65,00 \%$ \\
\hline 8 & $\begin{array}{l}\text { Senang mencari dan memecahkan masalah soal- } \\
\text { soal }\end{array}$ & $67,14 \%$ \\
\hline \multicolumn{2}{|l|}{ Skor Rata-rata } & $69,60 \%$ \\
\hline
\end{tabular}

Sumber: Data Primer yang Diolah

Dari data di atas diketahui bahwa terdapat lima indikator yang belum mencapai kriteria minimal yang ditentukan yaitu indikator ulet menghadapi kesulitan (69,29\%), cepat bosan pada tugas-tugas rutin $(64,64 \%)$, dapat mempertahankan pendapatnya $(51,79 \%)$, tidak mudah melepaskan hal yang diyakini (65\%), dan senang mencari dan memecahkan masalah soa-soal $(67,14 \%)$. Dari data ini selanjutnya akan digunakan sebagai salah satu bahan refleksi.

4) Tahap Refleksi

Berdasarkan data yang ditampilkan di atas diketahui bahwa beberapa aspek Motivasi Belajar Akuntansi siswa belum optimal. Siswa yang bertanya tentang materi hanya sedikit. Siswa memilih untuk fokus mengerjakan soal yang diberikan dengan cara membagi soal tersebut dengan pasangannya. Dalam sesi sharing tidak banyak siswa yang mau mengungkapkan alasan dari jawabannya. Sebagian besar dari mereka terpaku pada hand out materi yang telah dibagikan. Selain itu juga siswa sering tidak menjawab pertanyaan yang diberikan atau menjawab secara bersama-sama.

Dari hasil di atas, disepakati bahwa akan dilakukan perbaikan pelaksanaan tindakan pada siklus 2 dimana pembelajaran dirancang dengan menggunakan soal yang lebih aplikatif dan tingkat kesulitannya lebih tinggi dengan harapan siswa akan berdiskusi dengan pasangannya guna menyelesaikan soal tersebut. Guru akan memberikan kesempatan kepada 
siswa untuk mengerjakan satu persatu soal kemudian siswa diminta untuk sharing dengan siswa lain pada setiap soalnya.

\section{c. Laporan Siklus 2}

Pembelajaran Akuntansi dengan Metode Pembelajaran Kooperatif Teknik Think Pair Share siklus 2 dilaksanakan pada tanggal 2 April 2012 pada jam pelajaran keenam sampai jam kedelapan dengan materi yang sama yaitu menghitung mutasi dana kas kecil. Adapun tahapan yang dilakukan sebagai berikut:

1) Tahap Perencanaan

Pembelajaran Akuntansi dengan Metode Pembelajaran Kooperatif Teknik Think Pair Share siklus 2 disiapkan pula beberapa perlengkapan yang diperlukan yaitu rencana pelaksanaan pembelajaran (RPP), lembar observasi, angket, catatan lapangan, materi dan soal latihan.

2) Tahap Pelaksanaan

RPP yang telah dipersiapkan sebelumnya selanjutnya diimplementasikan dalam kegiatan pembelajaran di kelas. Secara rinci pelaksanaan tindakan yang dilakukan adalah:

a) Kegiatan Awal

(1) Guru mengkondisikan kelas

(2) Guru menyampaikan inti topik

b) Kegiatan Inti

(1) Guru mengumumkan daftar pasangan

(2) Masing-masing siswa diberikan soal

(3) Siswa diminta untuk bekerjasama dengan pasangannya

(4) Siswa diminta untuk sharing

c) Kegiatan Akhir

(1) Guru bersama-sama dengan siswa melakukan konfirmasi

(2) Guru bersama-sama dengan siswa menyimpulkan hasil pembelajaran.

3) Tahap Pengamatan

Dengan menggunakan lembar observasi yang telah disusun sebelumnya dilakukan pengamatan terhadap Motivasi Belajar Akuntansi siswa kelas X Akuntansi 2 dengan memperhatikan indikator yang telah ditentukan. Dari pengamatan yang dilakukan diperoleh data sebagai berikut: 
Tabel 6. Skor Motivasi Belajar Akuntansi Siswa Siklus 2

\begin{tabular}{|c|l|c|}
\hline No & \multicolumn{1}{|c|}{ Indikator } & Skor \\
\hline 1 & Tekun menghadapi tugas & $90,81 \%$ \\
\hline 2 & Ulet menghadapi kesulitan & $79,78 \%$ \\
\hline 3 & Memiliki minat terhadap pelajaran & $83,09 \%$ \\
\hline 4 & Lebih senang bekerja mandiri & $77,94 \%$ \\
\hline 5 & Cepat bosan pada tugas-tugas rutin & $75,74 \%$ \\
\hline 6 & Dapat mempertahankan pendapatnya & $76,10 \%$ \\
\hline 7 & Tidak mudah melepaskan hal yang diyakini & $81,99 \%$ \\
\hline 8 & Senang mencari dan memecahkan masalah soal-soal & $83,09 \%$ \\
\hline Skor Rata-rata & $81,07 \%$ \\
\hline
\end{tabular}

Sumber: Data Primer yang Diolah

Apabila dilihat skor pada setiap indikator Motivasi Belajar Akuntansi telah mencapai kriteria minimal yang telah ditetapkan sebelumnya yaitu sebsar 75\%. Kemudian apabila dilihat dari skor keseluruhan juga diperoleh skor Motivasi Belajar Akuntansi yang telah melampaui kriteria minimal dimana diperoleh skor $81,07 \%$.

4) Tahap Refleksi

Hasil penelitian siklus 2 menunjukkan adanya peningkatan skor indikator yang meliputi Motivasi Belajar Akuntansi siswa. Rencana perbaikan yang direncanakan pada siklus 1 dapat dilaksanakan dengan baik pada siklus 2. Hal ini terlihat dari data observasi pada siklus 2 dimana delapan indikator Motivasi Belajar Akuntansi siswa telah mencapai kriteria minimal yang telah ditentukan yaitu sebesar $75 \%$. Oleh karena itu pembahasan materi menghitung mutasi dana kas kecil dicukupkan sampai dengan siklus 2.

\section{d. Data Angket Siklus 1 dan Siklus 2}

Angket disebarkan pada akhir pembelajaran baik pada siklus 1 maupun siklus 2 dimana butir pernyataan pada angket tersebut sama. Dari angket yang telah didistribusikan pada siklus 1 dan siklus 2 dapat ditampilkan data sebagai berikut:

Tabel 7. Data Angket Motivasi Belajar Akuntansi Siswa Siklus 1 dan Siklus 2

\begin{tabular}{|c|l|c|c|}
\hline \multirow{2}{*}{ No } & \multicolumn{1}{|c|}{ Indikator } & \multicolumn{2}{c|}{ Skor } \\
\cline { 3 - 4 } & & Siklus 1 & Siklus 2 \\
\hline 1 & Tekun menghadapi tugas & $73,57 \%$ & $77,76 \%$ \\
\hline 2 & Ulet menghadapi kesulitan & $77,62 \%$ & $76,47 \%$ \\
\hline 3 & Memiliki minat terhadap pelajaran & $74,29 \%$ & $77,94 \%$ \\
\hline 4 & Lebih senang bekerja mandiri & $61,67 \%$ & $67,65 \%$ \\
\hline 5 & Cepat bosan pada tugas-tugas rutin & $60,00 \%$ & $67,89 \%$ \\
\hline 6 & Dapat mempertahankan pendapatnya & $73,81 \%$ & $76,23 \%$ \\
\hline
\end{tabular}




\begin{tabular}{|c|l|c|c|}
7 & Tidak mudah melepaskan hal yang diyakini & $72,14 \%$ & $76,47 \%$ \\
\hline 8 & Senang mencari dan memecahkan masalah soal-soal & $73,81 \%$ & $79,90 \%$ \\
\hline Skor rata-rata & $70,86 \%$ & $75,04 \%$ \\
\hline
\end{tabular}

Sumber: Data Primer yang Diolah

Berdasarkan data siklus 1 di atas menunjukkan bahwa hanya terdapat 1 indikator saja yang telah mencapai kriteria minimal yaitu indikator ulet menghadapi kesulitan yaitu sebesar $77,62 \%$. Sedangkan ketujuh indikator lainnya belum mencapai $75 \%$. Pada siklus 2 mengalami perubahan dimana hanya terdapat 2 indikator saja yang belum mencapai kriteria minimal yaitu indikator lebih senang bekerja mandiri 67,65\% dan cepat bosan pada tugastugas rutin $67,89 \%$ kemudian terdapat 6 indikator yang sudah mencapai kriteria minimal yang ditentukan.

\section{e. Data Wawancara}

Untuk mengetahui kredibilitas data yang diperoleh dilakukan cross check dengan wawancara. Dari wawancara yang telah dilakukan diperoleh data terkait dengan Motivasi Belajar Akuntansi. Berikut ini disajikan ringkasan data hasil wawancara pada masing-masing indikator Motivasi Belajar Akuntansi sebagai berikut:

1) Tekun menghadapi tugas

(a) $100 \%$ siswa mengatakan bahwa mereka mengerjakan seluruh soal yang diberikan dengan tuntas

(b) $42,86 \%$ siswa teliti dalam mengerjakan soal

2) Ulet menghadapi kesulitan

(a) 54,28\% siswa mengatakan yakin yakin dapat meyelesaikan kesulitan tersebut

(b) $100 \%$ siswa akan bertanya pada teman, guru atau mencari solusinya di buku jika menemui kesulitan

3) Memiliki minat terhadap pelajaran

(a) $40 \%$ siswa menjawab selalu mempersiapkan perlengkapan yang diperlukan

(b) 51,43\% siswa menjawab selalu memperhatikan pelajaran

4) Lebih senang bekerja mandiri

(a) 94,29\% siswa bertanggungjawab dengan ikut mengerjakan soal.

(b) $37,14 \%$ siswa tidak mencontek saat mengerjakan tugas individu

5) Cepat bosan pada tugas-tugas rutin

(a) $74,29 \%$ siswa mengaku bosan apabila pembelajaran Akuntansi dilaksanakan dengan ceramah terdapat 
(b) $42,86 \%$ siswa suka ketika ceramah dikombinasikan dengan latihan soal

6) Dapat mempertahankan pendapatnya

(a) Terdapat $51,43 \%$ siswa yang menjawab mampu memberikan argumen atau alasan dari jawabannya

(b) $100 \%$ siswa ingin mempertahankan argumennya

7) Tidak mudah melepaskan hal yang diyakini

(a) $77,14 \%$ siswa mengatakan yakin dengan jawaban pekerjaannya

(b) $100 \%$ siswa yakin dengan latihan soal akan mempermudah mereka dalam memahami pelajaran Akuntansi

8) Senang mencari dan memecahkan masalah soal-soal

(a) $65,71 \%$ menjawab senang memecahkan soal latihan

(b) $94,28 \%$ siswa tertantang untuk mengerjakan soal yang memiliki tingkat kesulitan yang semakin tinggi.

\section{Pembahasan}

Dari penelitian yang dilakukan yang meliputi perencanaan, tindakan, pengamatan dan refleksi telah diperoleh data seperti yang telah tersebut di atas. Dalam pelaksanaan pembelajaran dengan Metode Pembelajaran Kooperatif Teknik Think Pair Share (TPS) baik pada siklus 1 maupun siklus 2 siswa menunjukkan aktivitas-aktivitas yang mencerminkan adanya motivasi untuk belajar. Untuk lebih jelasnya berikut ini disajikan data Motivasi belajar Akuntansi siswa sebelum penelitian, siklus1 dan siklus 2:

Tabel 8. Perbandingan Skor Motivasi Belajar Akuntansi Berdasarkan Observasi pada Siklus 1 dan Siklus 2

\begin{tabular}{|l|c|c|c|c|c|}
\hline \multirow{2}{*}{ Indikator } & \multicolumn{3}{c|}{ Skor (\%) } & \multicolumn{2}{c|}{$\begin{array}{c}\text { Peningkatan } \\
(\%)\end{array}$} \\
\cline { 2 - 6 } & Pra* & Siklus 1 & Siklus 2 & Pra*-1 & $\mathbf{1 - 2}$ \\
\hline Tekun menghadapi tugas & 53,79 & 84,29 & 90,81 & 30,50 & 6,52 \\
\hline Ulet menghadapi kesulitan & 55,30 & 69,29 & 79,78 & 13,98 & 10,49 \\
\hline Memiliki minat terhadap pelajaran & 62,12 & 78,57 & 83,09 & 16,45 & 4,52 \\
\hline Lebih senang bekerja mandiri & 46,59 & 76,07 & 77,94 & 29,48 & 1,87 \\
\hline Cepat bosan pada tugas-tugas rutin & 56,06 & 64,64 & 75,74 & 8,58 & 11,09 \\
\hline Dapat mempertahankan pendapatnya & 50,38 & 51,79 & 76,10 & 1,41 & 24,32 \\
\hline $\begin{array}{l}\text { Tidak mudah melepaskan hal yang } \\
\text { diyakini }\end{array}$ & 51,14 & 65,00 & 81,99 & 13,86 & 16,99 \\
\hline Senang mencari dan memecahkan & 51,14 & 67,14 & 83,09 & 16,01 & 15,95 \\
\hline
\end{tabular}


Jurnal Pendidikan Akuntansi Indonesia, Vol. X, No. 1, Tahun 2012

Hana Kurniawan \& Andian Ari Istiningrum

Halaman 114 - 134

\begin{tabular}{|l|c|c|c|c|c|}
\hline masalah soal-soal & & & & & \\
\hline Skor rata-rata & 53,31 & 69,60 & 81,07 & 16,28 & 11,47 \\
\hline
\end{tabular}

Sumber: Data Primer yang Diolah

Ket: * Data Observasi Awal

Berdasarkan data di atas dapat dilihat bahwa terjadi peningkatan skor Motivasi Belajar Akuntansi dari sebelum pembelajaran kooperatif Think Pair Share (TPS) ke siklus 1 sebesar 16,28\%. Peningkatan juga terjadi sebesar 11,47\% jika dilihat dari siklus 1 ke siklus 2 .

Berikut ini adalah data dari angket tersebut:

Tabel 9. Perbandingan Data Angket Motivasi Belajar Akuntansi Pada Siklus 1 dan Siklus 2

\begin{tabular}{|l|c|c|c|}
\hline \multirow{2}{*}{ Indikator } & \multicolumn{2}{c|}{ Skor Siklus } & Peningkatan \\
\cline { 2 - 4 } & $\mathbf{1}$ & $\mathbf{2}$ & $\mathbf{1}$ ke 2 \\
\hline Tekun menghadapi tugas & $73,57 \%$ & $77,76 \%$ & $4,19 \%$ \\
\hline Ulet menghadapi kesulitan & $77,62 \%$ & $76,47 \%$ & $-1,15 \%$ \\
\hline Memiliki minat terhadap pelajaran & $74,29 \%$ & $77,94 \%$ & $3,66 \%$ \\
\hline Lebih senang bekerja mandiri & $61,67 \%$ & $67,65 \%$ & $5,98 \%$ \\
\hline Cepat bosan pada tugas-tugas rutin & $60,00 \%$ & $67,89 \%$ & $7,89 \%$ \\
\hline Dapat mempertahankan pendapatnya & $73,81 \%$ & $76,23 \%$ & $2,42 \%$ \\
\hline Tidak mudah melepaskan hal yang diyakini & $72,14 \%$ & $76,47 \%$ & $4,33 \%$ \\
\hline Senang mencari dan memecahkan masalah soal-soal & $73,81 \%$ & $79,90 \%$ & $6,09 \%$ \\
\hline Skor rata-rata & $70,86 \%$ & $75,04 \%$ & $4,18 \%$ \\
\hline
\end{tabular}

Sumber: Data Primer yang Diolah

Berdasarkan data yang telah ditampilkan di atas, baik data observasi, angket maupun wawancara dapat dilanjutkan ke tahap berikutnya yaitu penarikan kesimpulan. Berikut ini penarikan kesimpulan dilakukan baik secara keseluruhan Motivasi Belajar Akuntansi maupun indikator-indikator yang melingkupinya:

1. Indikator tekun menghadapi tugas

Terjadi peningkatan skor dari sebelum pembelajaran Think Pair Share ke siklus 1 sebesar 30,5\% dan peningkatan dari siklus 1 ke siklus 2 sebesar 6,52\%. Peningkatan skor Motivasi Belajar Akuntansi siswa juga ditunjukkan dari data angket dimana terjadi peningkatan sebesar 4,19\% dari siklus 1 ke siklus 2. Berdasarkan data wawancara juga terungkap bahwa seluruh siswa mengerjakan soal dengan tuntas dan 48,57\% siswa kadang-kadang teliti dan sisanya menyatakan teliti dalam mengerjakan soal. Dalam pembelajaran Kooperatif Think Pair Share, kelas menjadi lebih terkondisi bagi siswa untuk mau mengerjakan soal yang diberikan guru secara tuntas. Hal ini sejalan dengan pendapat Wina Sanjaya (2008) bahwa siswa menjadi lebih tekun dalam mengerjakan soal yang diberikan 


\section{Jurnal Pendidikan Akuntansi Indonesia, Vol. X, No. 1, Tahun 2012 Hana Kurniawan \& Andian Ari Istiningrum \\ Halaman 114 - 134}

guru. Pembelajaran ini dapat menambah kemampuan berpikir siswa dari berbagai sumber serta melalui belajar dengan siswa lain sehingga siswa tidak hanya bergantung pada guru.

2. Indikator ulet menghadapi kesulitan

Sebelum pembelajaran Think Pair Share diketahui skor indikator sebesar 55,3\% kemudian terjadi peningkatan pada siklus 1 sebesar 13,98\% dan meningkat lagi di siklus 2 sebesar 10,49\%. Dalam data angket ternyata justru terjadi penurunan $1,15 \%$. Penurunan ini dikarenakan pada siklus kedua siswa diberikan materi yang sama dengan siklus 1, sehingga siswa tidak merasa tidak perlu untuk mengajukan pertanyaan terhadap materi. Soal yang digunakan pada siklus 2 juga memberikan pengaruh dimana soal praktik yang harus dikerjakan siswa pada dasarnya aplikasi dari teori yang telah dipahami siswa sebelumnya. Selain itu, bentuk soal yang lebih aplikatif ternyata memberikan dampak terhadap keyakinan siswa untuk dapat menyelesaikannya. Dari uraian di atas memang terdapat perbedaan, akan tetapi data wawancara menyebutkan bahwa ketika siswa menemui kesulitan mereka akan berusaha mencari pemecahannya dengan bertanya kepada teman, mencari di buku dan bertanya pada guru. Penjelasan di atas dapat disimpulkan bahwa sebenarnya siswa mengalami peningkatan skor pada indikator ini. Ketika pembelajaran memasuki tahapan Pair, siswa memiliki kesempatan untuk mengkolaborasikan kemampuannya dengan pasangannya guna mengerjakan soal yang diberikan. Kesulitan yang dihadapi akan didiskusikan oleh pasangan-pasangan tersebut kemudian apabila dalam diskusi belum ditemukan jawabannya, mereka akan berusaha untuk mencari pemecahannya dengan bertanya pada guru, sehingga keuletan siswa meningkat. Hal ini sesuai dengan komponen dalam pembelajaran kooperatif yaitu tugas kooperatif dan struktur insentif yang mampu memotivasi siswa untuk dapat menyelesaikan tugas yang diberikan (Wina Sanjaya, 2008).

3. Indikator memiliki minat terhadap pelajaran

Terjadi peningkatan skor indikator dimana di awali dengan skor 62,12\% meningkat menjadi $78,57 \%$ dan meningkat lagi menjadi $83,09 \%$. Selaras dengan data tersebut, baik angket maupun wawancara menampilkan data yang memiliki kecenderungan sama. Pada angket terjadi peningkatan skor sebesar 3,66\% dan juga diketahui bahwa hanya $25,71 \%$ siswa yang tidak menyiapkan perlengkapan yang dibutuhkan untuk pembelajaran Akuntansi kemudian juga terdapat 37,14\% siswa kadang-kadang tidak memperhatikan pelajaran dan sisanya selalu atau sering memperhatikan pelajaran. Dengan diterapkannya 


\section{Jurnal Pendidikan Akuntansi Indonesia, Vol. X, No. 1, Tahun 2012 Hana Kurniawan \& Andian Ari Istiningrum \\ Halaman 114 - 134}

pembelajaran Kooperatif Think Pair Share mampu memberikan dampak positif terhadap suasana kelas yang terbangun. Adanya tiga tahapan penting di dalamnya mampu menciptakan pembelajaran yang menarik, bermakna dan memberi tantangan. Seperti yang diungkapkan Sugihartono et. al (2007) bahwa dengan adanya kondisi pembelajaran seperti di atas mampu membuat siswa termotivasi. Hal ini dapat diwujudkan dengan memperhatikan pelajaran dan juga menyiapkan perlengkapan yang dibutuhkan selama pembelajaran.

4. Indikator lebih senang bekerja mandiri

Pada indikator ini terdapat peningkatan sebesar 29,48\% dari data awal ke siklus 1 dan 1,87\% dari siklus 1 ke siklus 2 . Sedangkan data angket menunjukkan peningkatan sebesar $5,98 \%$. Sebanyak 94,29\% siswa mengaku bahwa mereka tidak menggantungkan jawaban kepada temannya ketika bekerja dalam kelompok akan tetapi pada saat siswa harus mengerjakan tugas individu lebih dari 50\% siswa mengaku mencontek. Pada dasarnya siswa memiliki tanggungjawab terhadap tugas yang diberikan pada dirinya. Hal ini ditunjukkan dengan adanya keinginan siswa untuk menyelesaikan soal tersebut secara bersama-sama ketika berpasangan dengan siswa lain. Sedangkan mengenai perilaku mencontek yang diutarakan siswa saat wawancara lebih mengarah kepada jika siswa sedang mengikuti ulangan harian sebelumnya bukan pada saat mengikuti pembelajaran Kooperatif Think Pair Share. Wina Sanjaya (2008) mengemukakan bahwa dengan adanya prinsip-prinsip kooperatif dalam pembelajaran akan melatih siswa untuk lebih bertanggungjawab dalam belajar. Pembelajaran ini dapat melatih tanggungjawab siswa dalam belajar. Dengan adanya tanggungjawab siswa dalam belajar, kemandirian siswa dalam belajar akan dapat ditingkatkan. Suksesnya pasangan yang ada didukung suksesnya individu-individu di dalamnya yang mandiri.

5. Indikator cepat bosan pada tugas-tugas rutin

Peningkatan sebesar $8,58 \%$ diperoleh dari data awal ke siklus 1 dan peningkatan sebesar 11,09\% dari siklus 1 ke siklus 2. Berdasarkan data angket yang diperoleh, terjadi kenaikan skor sebesar 7,89\%. Jika di cross check dengan data wawancara sebagian besar atau $74,28 \%$ siswa mengatakan bahwa mereka bosan jika pembelajaran dengan ceramah kemudian terjadi penurunan yaitu hanya $34,28 \%$ siswa yang merasa bosan jika pembelajaran Akuntansi disajikan dengan ceramah ditambah dengan latihan soal. Tujuan dari pembelajaran TPS adalah untuk mempengaruhi pola interaksi siswa (Yatim Riyanto, 


\section{Jurnal Pendidikan Akuntansi Indonesia, Vol. X, No. 1, Tahun 2012 Hana Kurniawan \& Andian Ari Istiningrum \\ Halaman 114 - 134}

2009). Interaksi yang terjadi begitu pembelajaran ini diselenggarakan adalah interaksi siswa dengan siswa lain menjadi lebih efektif begitu pula interaksi siswa dengan guru menjadi lebih komunikatif. Kondisi ini memberikan dampak terhadap peningkatan semangat dan antusiasme siswa untuk mengikuti pembelajaran kemudian mereka tidak terjebak dengan kegiatan monoton dan mekanis dalam belajar.

6. Indikator dapat mempertahankan pendapatnya

Terjadi peningkatan skor dari data awal ke siklus 1 sebesar 1,41\% dan 24,32\% dari siklus 1 ke siklus 2. Dilihat dari data angket terjadi peningkatan skor sebesar 2,42\%. Kemudian dalam wawancara diperoleh data bahwa pada dasarnya siswa mengetahui dan mampu menjelaskan argumen atau alasan dari pekerjaan mereka. Selain itu jika terjadi perbedaan dalam mengerjakan soal, semua siswa mengatakan hal yang sama yaitu memilih membuktikan pendapat siapa yang benar. Pembelajaran TPS yang dihadirkan di kelas membuat individu-individu di dalamnya memiliki pemahaman yang lebih karena selain dengan penjelasan lisan, siswa juga melakukan diskusi. Tidak hanya sampai diskusi selanjutnya siswa juga melakukan konfirmasi terhadap hasil diskusi pada akhir pembelajaran, sehingga siswa dapat menjawab pertanyaan yang ada dan memiliki argumen yang tepat atas jawaban tersebut. Sesuai dengan pendapat Wina Sanjaya (2008) bahwa pembelajaran kooperatif TPS dapat mengembangkan kemampuan mengeluarkan ide atau gagasan siswa secara verbal. Dari sinilah siswa lebih mampu mempertahankan pendapatnya.

7. Indikator tidak mudah melepaskan hal yang diyakini

Diperoleh peningkatan skor sebesar 13,86\% dari data awal ke siklus 1 dan 16,99\% dari siklus 1 ke siklus 2. Peningkatan dari data angket ditunjukkan sebesar 4,33\% kemudian didukung dengan wawancara dimana $77,14 \%$ siswa yakin dengan apa yang mereka pahami dan juga yakin dengan hasil pekerjaan mereka. Pembelajaran ini merangsang siswa untuk mengembangkan kemampuannya untuk menguji ide dan pemahaman yang dimiliki (Wina Sanjaya, 2008). Dari keyakinan siswa yang lebih tinggi dalam mengerjakan soal yang ditimbulkan sebelumnya dapat memberikan pengaruh terhadap kemantapan siswa dalam mengutarakan pendapat ataupun dalam mengerjakan soal-soal karena pada dasarnya siswa telah mantap dengan yang diyakini sehingga tidak mudah untuk melepaskan yang mereka yakini itu. 


\section{Jurnal Pendidikan Akuntansi Indonesia, Vol. X, No. 1, Tahun 2012 Hana Kurniawan \& Andian Ari Istiningrum \\ Halaman $114-134$}

8. Indikator senang mencari dan memecahkan masalah soal-soal

Terjadi peningkatan skor sebesar 16,01\% dari data awal ke siklus 1 dan 15,95\% dari siklus 1 ke siklus 2. Selaras dengan data observasi, data angket juga menunjukkan adanya peningkatan skor sebesar 6,09\% dan juga didukung data wawancara yang mengatakan bahwa hanya $2,86 \%$ siswa yang tidak senang jika harus mengerjakan soal kemudian 94,28\% siswa merasa tertantang untuk mengerjakan soal yang memiliki tingkat kesulitan yang lebih sulit dari sebelumnya. Kemampuan siswa yang terkolaborasi dengan baik melalui pasangan-pasangan yang dibentuk berdasarkan kemampuan siswa yang heterogen memberikan dampak positif bagi mereka. Dengan timbulnya interaksi belajar yang efektif di dalamnya mampu memberikan dampak terhadap peningkatan kemampuan siswa dalam menggunakan informasi dan kemampuan belajar abstrak menjadi lebih nyata (Wina Sanjaya, 2008). Individu-individu dalam pasangan tersebut tertantang untuk mengerjakan soal-soal yang memiliki tingkat kesulitan lebih tinggi karena dengan mereka bekerjasama soal yang tadinya cukup sulit jika harus dikerjakan sendiri menjadi lebih mudah dengan dikerjakan bersama-sama. Kecenderungan siswa yang lebih senang dalam memecahkan masalah dan soal-soal juga dapat dikonformasi dengan pendapat Yatim Riyanto (2009) yang menyatakan bahwa pembelajaran kooperatif yang diterapkan di kelas dapat mengakomodir siswa dalam belajar berpikir, memecahkan masalah dan mengintegrasikan pengetahuannya.

Dari pembahasan terhadap kedelapan indikator Motivasi Belajar Akuntansi secara garis besar diperoleh peningkatan skor pada setiap indikatornya. Sesuai dengan pendapat Wina Sanjaya (2008) bahwa interaksi yang ditimbulkan dalam pembelajaran Kooperatif Teknik Think Pair Share dapat memicu peningkatan motivasi dan memberikan rangsangan untuk berpikir. Selain itu juga sejalan dengan Sumiyati dan Tika Wulan Novita (2009) yang menyebutkan bahwa dengan diterapkannya Metode Pembelajaran Kooperatif Teknik Think Pair Share dapat meningkatkan motivasi belajar siswa. Oleh karena itu, dengan ini telah terbukti bahwa dengan penerapan Metode pembelajaran Kooperatif Teknik Think Pair Share (TPS) dapat meningkatkan Motivasi Belajar Akuntansi Kompetensi Dasar Menghitung Mutasi Dana Kas Kecil siswa kelas X Akuntansi 2 SMK Negeri 7 Yogyakarta Tahun Ajaran $2011 / 2012$.

\section{Penutup}

Berdasarkan hasil penelitian dan pembahasan pada bab IV dapat disimpulkan bahwa Penerapan Metode Pembelajaran Kooperatif Teknik Think Pair Share (TPS) dapat 
meningkatkan Motivasi Belajar Akuntansi Kompetensi Dasar Menghitung Mutasi Dana Kas Kecil siswa kelas X Akuntansi 2 SMK Negeri 7 Yogyakarta tahun ajaran 2011/2012 yang dibuktikan dengan adanya peningkatan persentase skor Motivasi Belajar Akuntansi yang diambil melalui observasi dengan lembar observasi diperoleh skor sebesar 53,31\% sebelum penerapan Pembelajaran Kooperatif Teknik Think Pair Share (TPS) kemudian meningkat menjadi $69,60 \%$ pada siklus 1 atau terjadi peningkatan sebesar 16,28\%. Selanjutnya pada siklus 2 juga terjadi peningkatan sebesar $11,47 \%$ atau diperoleh skor sebesar $81,07 \%$. Selain itu berdasarkan angket yang didistribusikan kepada siswa dapat disimpulkan pula bahwa terjadi peningkatan skor Motivasi Belajar Akuntansi siswa sebesar 4,18\% dimana skor pada siklus 1 sebesar 70,86\% meningkat menjadi 75,04\% pada siklus 2. Dengan cross check yang dilakukan melalui wawancara dapat disimpulkan pula bahwa dengan diterapkannya Metode Pembelajaran Kooperatif Teknik Think Pair Share (TPS) dapat meningkatkan Motivasi Belajar Akuntansi siswa yang dapat dilihat dari sebagian besar jawaban siswa atas pertanyaan-pertanyaan yang diberikan yang konsisten dengan data observasi dan angket.

\section{E. Daftar Pustaka}

Dimyati \& Mudjiono. (2009). Belajar dan Pembelajaran. Jakarta: PT. Rineka Cipta.

Etin Solihatin \& Raharjo. (2007). Cooperative Learning Analisis Model Pembelajaran IPS. Jakarta: Bumi Aksara.

Hendi Somantri. (2005). Memahami Akuntansi SMK Seri B. Bandung: Armico

Muhibbin Syah. (2011). Psikologi Belajar. Jakarta: CV Alfabeta.

Mulyasa. (2009). Menjadi Guru Profesional: Menciptakan Pembelajaran Kreatif dan Menyenangkan. Bandung: PT. Remaja Rosdakarya.

Sardiman AM. (2011). Interaksi dan Motivasi Belajar Mengajar. Jakarta: PT. Raja Grafindo Persada.

Sugihartono. et. al. (2007). Psikologi Pendidikan. Yogyakarta: UNY Press.

Sugiyono. (2010). Metode Penelitian Pendidikan. Bandung: CV Alfabeta.

Sumiyati. (2009). "Penerapan Pembelajaran Kooperatif Model Struktural Tipe Think Pair Share (TPS) untuk Meningkatkan Motivasi dan Hasil Belajar Siswa pada Mata Pelajaran Ekonomi Kelas X-A SMA Negeri I Probolinggo". Diambil dari: http://library.um.ac.id/ptk/index.php?mod=detail\&id=37292, pada tanggal 9 Desember 2011. 
Jurnal Pendidikan Akuntansi Indonesia, Vol. X, No. 1, Tahun 2012

Hana Kurniawan \& Andian Ari Istiningrum

Halaman 114 - 134

Tika Wulan Novita. (2009). "Penerapan Model Pembelajaran Kooperatif Think Pair Share (TPS) untuk Meningkatkan Motivasi dan Prestasi Belajar Biologi Siswa Kelas X SMA Kertanegara Malang". Diambil dari: http://library.um.ac.id/ptk/index.php?mod=detail\&id=40540, pada tanggal 9 Desember 2011

Toto Sucipto, Moelyati \& Sumardi. 2009. Akuntansi 2 untuk SMK Kelas XI. Jakarta : Yudhistira.

Toto Sucipto. et. al. (2009). Akuntansi 2 Untuk SMK Kelas XI. Jakarta: Yudhistira.

Wina Sanjaya. (2008). Strategi Pembelajaran Berorientasi Standar Proses Pendidikan. Jakarta : Kencana.

Yatim Riyatno (2009). Paradigma Baru Pembelajaran: Sebagai Referensi Bagi Pendidik dalam Implementasi Pembelajaran Yang Efektif dan Berkualitas. Jakarta: Kencana. 